\title{
自傷行為によるロ䨐欠損に対する形成手術の経験
}

\author{
森聖治・橋本温・上野純子・内海俊明 \\ 谷岡博昭
}

\section{Plastic and reconstructive surgery for defect of lip due to self-mutilation}

\author{
Seiji Mori - Yutaka Hashimoto • Junko Ueno \\ Toshiaki Utsumi $\cdot$ Hiroaki TANIOKA
}

\begin{abstract}
The authors recently experienced a plastic surgery (Bernard's method) for extensive defect of lower lip due to self-mutilation. The patient is a 7-year-old girl suspected LeschNyhan syndrome.

The prognosis is now good with no recurrence and no problems. The authors will discuss the treatment after operation and countermeasure of self-mutilation in this paper.
\end{abstract}

Key words: self-mutilation (自笏行為), Bernard's method (Bernard 法)

\section{緒言}

顎顔面領域に生じた悪性腫瘍や外伤による実質欠損は その程度により, 種々の再建術が行われている. 今回わ れわれは自傷行為により下唇に欠損を生じた脳性麻痺の 患者に対し, Bernard 法による口唇形成術を行ったので 手術法, 術後管理を中心に考察を加えて報告する。

\section{症例}

患者：5歳 1 か月 女兒.

初診：昭和61年10月回日.

主 訴：自傷行為による下唇欠損

家族歴：母系の両親がいとこ結婚だったが，親族に特 に遺伝的疾患は認めなかった。

出生歴: 妊娠16週に母親が膀脱炎にて抗生剂内服し, 同時期，一時的に胎児心音聴取不能となったが，その後 の経過は問題なく, 昭和56年 9 月口日 $2,730 \mathrm{~g}$ 満期正常 分婏にて出生した。

爱娞大学医学部俻科口腔外科学教室

(主任：谷岡博昭教授)

Department of Oral and Maxillofacial Surgery,

Ehime University School of Medicine (Chief:

Prof. Hiroaki Tanioka)

受付日: 平成 2 年 5 月 23 日

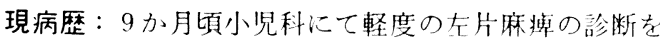
受けた。 2 歳頃, 右手の人差し指を曲げてッメで下唇を 擦過したり，泼を咬むなどの自傷行為を繰り返し、は じめは裂賃が認められ，次第に下愿の一部尔損を生じ た. 3 歳頃には近辺にあるものに自ら下㴿をぶつけると いら自傷行為も加わり下唇の広籁な史質欠損㧍よび下硕 乳前歯の脱落を認めた。

現 症：初診時，患者の全身所見としては厓片麻瘏，

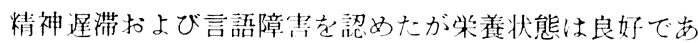
った，㕠㟇施設において作製したプロテクターを右上 肢洼着し手指による自傷行為の防止をはかっていた。

局所所見としては左右口角部赤唇をわずかに残し創部 は幅 $25 \mathrm{~mm}$ にわたり下唇からオトガイ部にわたる実頃 欠損を認めた。残存部の創部粘膜は発赤腫脹を認め潰陽 形成部位は易出血性であった。舌突出癖，流脠㧍上び咀 嗳障害を認め閉口不能であった。自傷行為は、ストレス に上り一層增強する傾向を示した（写真1）.

処置および経過：外来にて経過観察を続けていたが年 路 7 歳となり体重 $20 \mathrm{~kg}$, 身長 $113 \mathrm{~cm}$ で, 栄亘状態も 特に問題はなく精神的にも安定してきたため，また母親 と養護施設スタッフが形成手術を強く希望したため, 平 成元年 4 月 4 日全身麻醉下, Bernard 法にて口唇形成術 を施行した（写真2）。

左右夋唇㴖部に三角形の切開を加之た。底辺以外は頓 粘膜まで切開を加觉，同部位の皮庾は切除し粘膜弁を作 製した。このとき左右の顔面動脈の末梢を結紮した。粘 


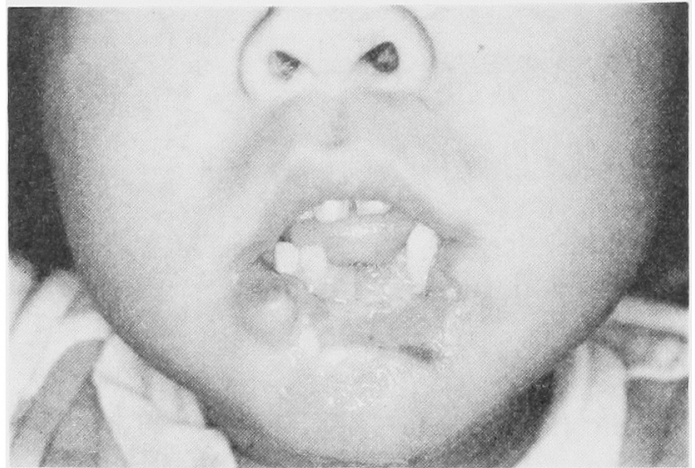

写真 1 初診時（昭和61年10月

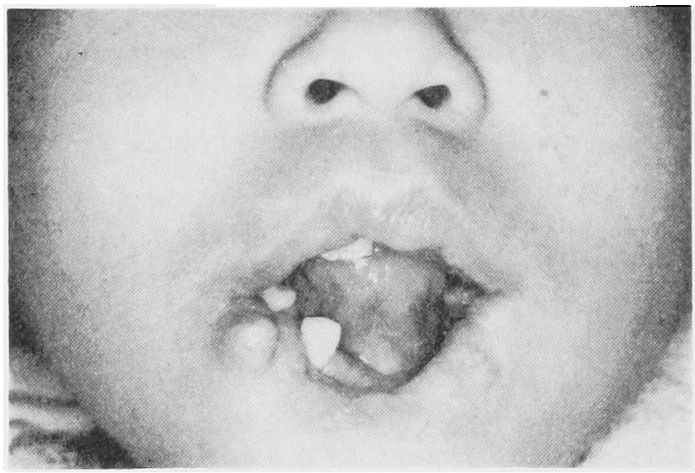

写直 2 術前（平成元年 4 月

暯弁俚，反転させて赤唇形成に使用した。手術時の設計 で下唇の欠損は幅 $25 \mathrm{~mm}$ であったため三角形の底辺は $12 \mathrm{~mm}$ 他の二辺は $22 \mathrm{~mm}$ とした. 久損部は新鲜面を得 るよう!右対称に切除したためやや方形を呈した．その 後才トガイ部に減張邚開を加え, 下唇形成術を終了した (図1).

術後管理としては，垥部の保蓝就よび感染を防ぐため 経口㨟取可能となるまで, 中心静脈栄盖を 12 日間行っ た。办分の経口摂取のみ術後第一日目より可としたが， 患者は空腹などによる不穏状態とはならず良好な翰液お よび栄埗管理を行らことがでさた。

また，自傷行為については左右両上肢にプロテクター （抑制带）を装着し手指による擦過を防いた。，精神面に おいては，生活リズムの確保および手術前後の精神面で の灾定を確保するための環境維持，具体的には，個人部 屋の使用・特定のドクターによる処虚・騒音, 人の出入 りの制限などにつとめ，母親に24時間付き添いをしてる らい自賃行為の防止を行った。程過良好飞て術後16日で 退院となったが，ての後焦謢施設にてスタッフにより注 意深い管理を行っている.

術後1か月に扣いて，自賃行為による口唇の損傷は認 められなかった（写真了）.
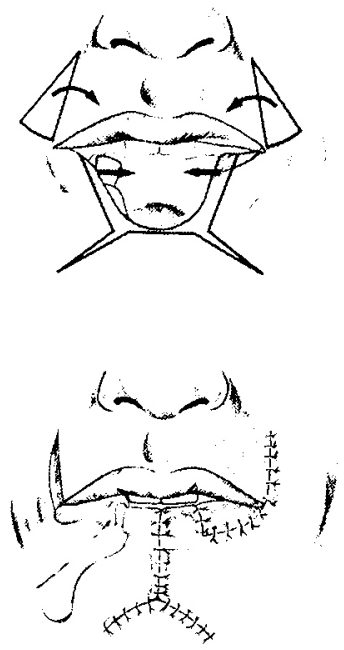

図 1 術式 (Bernard 法)

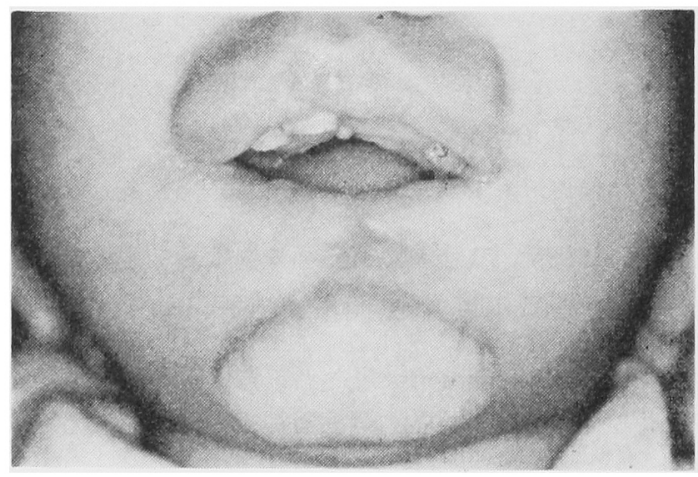

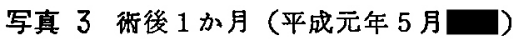

しかし, 術後 5 か月を経通後患者の精神状熊が多少不 安定となり口腔内粘膜への手指の擦過による発赤が多少 認められた（写真 4 ）が, 術後約 1 年を経過した現在経 過は良好である。

\section{考察}

自㑺行為（self-mutilation）性，心因性反応・知能障 害・脳障害・精神病などの際に認められるとされてい る が，本症例のごとく精神遅滞者に 2 歳ごろよりあ

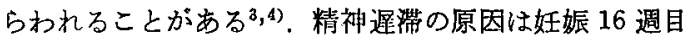
の一時的胎胃心拍数減少による脳への酸薪供給不足が最 も考えられた. Lかし, Lesch-Nyhan syndrome の可能 性む否定できない。 


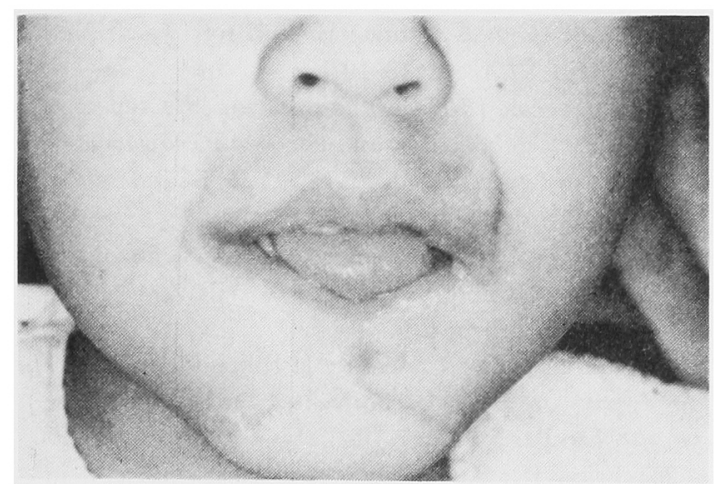

写真 4 術後 5 か月（平成元年 9 月回）

\section{Lesch-Nyhan syndrome ${ }^{5)}$}

自傷行為之錐体外路症状と精神発達掘湍を特徽的な臨

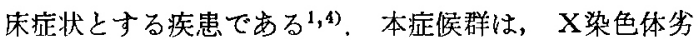
性遗伝の尿酸代謝異常で每り, hypoxanthine-guanine phosphoribosyltransferase (以下 HGPRT) という酵素 を先天的に欠損している1)ことが1967年 Secgmiller6) ら により証明された。 1959 年に Catel と Schmidt)によ りその臨床例が初めて報告され，1964年飞 Lesch と Nyhan により生化学的に原因が究明された疾患であ

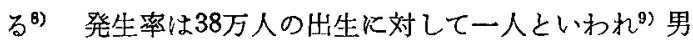
子のみに発症する(0)とされるが，州界でただ一例の女児 の患者が本邦に打いて，小笠原 ${ }^{11} に よ り$ 報告されてい る.

この症候群の診断は，淘尿酸血症・高尿酸尿症 ${ }^{12)}$ をは しめとする臨床検查值の異常によるが, 確定診断上重要 なるのとして赤血球や線維芽細胞の HGPRT の欠損)で あり，正常の1\%以下のことが多いとされている. 生化 学的には，HGPRT の活性の欠損によりプリン生合成 が亢進してクリシンが尿酸へとりこまれる率は，正常の 200 倍比達し㽷酸過剩産生となる ${ }^{13,14)}$.

自傷行為は， 2 歳頃 ${ }^{15\rangle}$ むくは崡の萌出とともにはし まる3) といわれている. 本症例で患者は, 自分の指,

下唇を咬むことが多く下唇の組織欠損を起こしたが先天 的痛覚障害によるもの文とは異なり，咬むと痛及を感じ るが，つい筊んでしまらといらよらに思われた。また， 精神的緊張で不随意運動が起こりやすいという錐体外路 症状の一般的症状もとなえていた.

本症候群に和いては，上記の理由により，10２0歳代 江高尿酸血症加腎結石を生し，慢性尿路感染綝り返

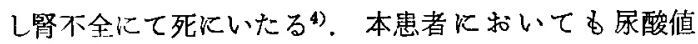
は, $9.8 \mathrm{mg} / \mathrm{d} l$ と高值を示した.ささらに, 術後半年後に 婜結石の猃断をらけている。しかし，総合病院小览科に 上り) Lesch-Nylian syndrome を疑われ精查治療を歓め られていたが，母親が拒否したために確定診断は得られ ていない.

\section{2. 自傷行為対策}

本疾患见最る特徽的な症状である自賃行為については 成因はいまだ不明で，预方方法も十分とい方るのはな い，治療炕いては，歯牙による自傷行為を避けるため 飞抜歯 ${ }^{3,16)}$ や上肢の抑制带などの対症的なもの，市るい

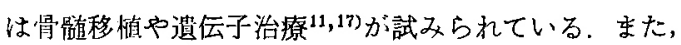
運動機能や精神発達に対してのリハビリは不可欠であ り，さらに自己身休烟着している患児の強い関心を外 界に向けるように，そして精神安定を保つための環境調

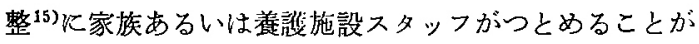
必要である。

\section{3. 手術法について ${ }^{18,18,20)}$}

下居実質火損に対しては種《の再廷術が行われている が，久損の部位・程度・手術の侵態の大きさ・箩美性和 よび咀嚼機能の回復などを考㤫し，Kazanjian and Converse ${ }^{20,21)}$ の原則以従い以下の観点から, Bernard 法 ${ }^{22 \sim 25)}$ とて行った（図1).

(1)下唇の十分な切除ができ，範畍がオトガイ部まで進 展した症例炕適与る。

(2)煩粘暯が保存できるので，再建する下唇の赤唇形成 に利用できる。

(3)過剩の皮们，㳙肉の trimming が最後に行らことが でき術後の機能障害と審美的変形の防止に役立つことが できる.

(1)顔面動脈の保存が可能である。

一般に下唇再建の基準として欠損が口唇の $1 / 3$ 以下の 場合に恃，創縁に新焦面を出した後，V字型，以字型， $V-Y$ 型 ${ }^{20,26)}$ などの切開により䂝存口唇を利用し，単純 縫合するのが一般的基準である．欠損が 1/3 1/2 亿及 ぶ症例に対しては唇弁反転手術27,28) (Abbe flaps ${ }^{29)}$, Estlander flaps ${ }^{30)}, \mathrm{Kazanjian}^{311}$ ) により 対向口唇を利

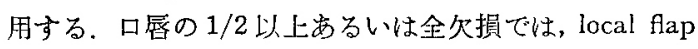

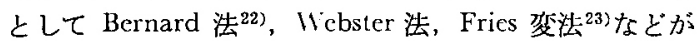
適用される。

また，厇範国軟部組織損傷例には，DP 皮弁などの遠 隔皮弁 ${ }^{32}$ 34) が使用されるが，審美的にも機能的にも局所 皮弁の方が有利で，遗隔皮弁は他の方法が適用できない 場合に最後の手段として用いるべきであるら。

\section{結語}

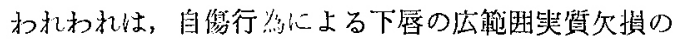
ある 7 藏女罗の症例を報告した。

形成手術は Bernard 氏法を用いたが，手術法，術後 管理，そして自傷行為の管理について検討を加えた。

\section{引用文 献}

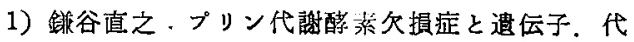


解 24: 301-308 1987.

2) Nyhan, W.L.: Clinical features of the LeschNyhan syndrome. Arch Intern Med 130:1861921972.

3) Dicks, J.L.: Lesch-Nyhan syndrome: a treatment planning dilemma. Ped Dent 4: 1271301982.

4) 有馬正高, 岡崎留瑟: Lesch-Nyhan 症候群. 内 科 31：1342-1346 1973.

5）小木信美, 片浦俊久, 他: Lesch-Nyhan 症候群 の一例。日口外誌 35：2394-2399 1989.

6) Seegmiller, J.E., Rosenbloom, F.M., et al.: Enzyme defect associated with a sex-linked human neurological disorder and excessive purine synthesis. Science 155:1682-1684 1967.

7) Catel, Von W. and Schmidt, J.. Über familiäre gichtische Diathese in Verbindung mit zerebralen und renalen Symptomen bei einem Kleinkind. Deutsche Medizinische Wochenschrift 84: 2145-2147 1959.

8) Lesch, M. and Nyhan W.L.: A familial disorder of uric acid metabolism and central nervous system function. Am J Mcd 36:5615701964.

9) Crawhall, J.C., Henderson J.F., et al.: Diagnosis and treatment of the Lesch-Nyhan syndrome. Pediat Res 6: 504-513 1972.

10) Nyhan, W.L., Sweetman, P.L., et al.: Genetics of an X-linked disorder of uric acid metabolism and cerebral function. Pediat Res 1: 5-13 1967.

11）小笠原信明，後藤治子：プリン代謝酷素異常症 一最近の進歩一 代的 24：291-298 1987.

12）有馬正高, 青木継稔：高尿酸血症の発生病理. 内科 27：204-210 1971 .

13) 織田敏次, 阿部 裕, 他編：内科七ミナーMET 4 痛風, 永井書店, 大阪, 1979, 179-191宣。

14）有馬正高, 竹下研三, 他：Lesch-Nyhan 症候 群。日本臨休 31：2488-2492 1973.

15) Anderson, L., Dancis, J., et al.: Behavioral contingencies and self-mutilation in LeschNyhan disease. J Consult Clin Psych 46:5295361978.

16) LaBanc, J. and Epker, B.N.: Lesch-Nyhan syndome: Surgical treatment in a case with lip chewing. A case report. J Max Fac Surg 9: 64-67 1981.

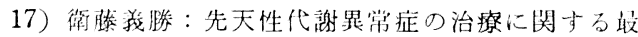
近の進歩。小児科部療 51：1608-1616 1988.

18) Naumann, H.H.: Head and neck surgery. Georg Thicme Verlag, Herdweg Stuttgart West Germany, 1980, p 80-91.

19) Barbosa, J.F.: Surgical treatment of head and neck tumors. Grune \& Stratton Inc., New York, 1974, p 118-127.

20) Converse, J.M.: Techniques for the repair of defects of the lips and cheeks.: Reconstructive plastic surgery. edition 2, W.B. Saunders Co, 1977, p 1544-1594.

21) Converse, J.M.: The treatment of facial injuries. edition 3, Williams \& Wilkins Co, Baltimore, 1974, p 954-955.

22) Bernard, C.. Cancer de la lèvr inférieureopèrè par un procèdè nouveau. Bull Mém Soc Chir Paris 3: 3571853.

23) Fries, R.: Advantages of a basic concept in lip reconstruction after tumour resection. J Maxillofac Surg 1: 13-18 1973.

24）堀越達郎, 简井英夫, 他: 図説顎 - 顔面 - 口膑 手術学。第 1 肘, 書林, 東京, 1976, 193-196 頁.

25) 大西真, 阿部正樹, 他 : Bernard 法 (Martin 変法）による下唇一次再建手術の経験，新舅崡 学会雑誌 6: p 60-68 1976.

26) Johnson, H.A.: "V" excision with less waste of normal skin. Plast \& Reconst Surg 33: 481-484 1964.

27）伊藤京逸, 丹下一郎, 他：Vermilion bordered flap を用いる夷辰修正手術（居弁反転法）形 成美容外科 2: 141-149 1959.

28）丹下一郎，高野行夫：口唇の後天性欠損に対す る唇弁反転手術。形成外科 9：263-267 1966.

29) Abbé, R.: A new plastic operation for the relief of deformity due to double harelip. Med Rec 53: 477-478 1898.

30) Estlander, J.A.: Classic reprint. Eine Methode aus der einen Lippe Substanzverluste der anderen zu ersetzen. (A method of reconstructing loss of substance in one lip from the other lip.) Translated from the German by Dr. Borje Sundell: Arch Klin Chir 14: 622 1972. Plast \& Reconstr Surg 42: 360-368 1968.

31) Kazanjian, V.H.: Estlander-Abbé operation in treating secondary harelip defomities and defects of the upper lip resulting from cancer. Plast \& Reconstr Surg 2: 307-325 1947.

32) 狝良 卓, 半田詔一, 他. 熊咬による顔面軟部 組織損伤の tubed pedicle flap 法に上る再建. 形成外科 14：502-506 1971.

33）飯塚桂司, 戸川消。他：能咬愘による複雑顔 面損㩐の再建。形成外科 24：422-426 1981.

34）滕田浄秀，，村瀬博文，他：DP 皮弁扰よび舌 弁の使用による下唇再建の 1 症例。日口外誌 24: 772-778 1978. 